\title{
Are trade and transport logistics activities mutually reinforcing? Some empirical evidences from ASEAN countries
}

\author{
Kee-hung Lai ${ }^{1}$, Yu Pang ${ }^{2}$, Christina W. Y. Wong ${ }^{1 *}$, Y. H. Venus Lun ${ }^{1}$ and Y. N. Eppie $\mathrm{Ng}^{1}$
}

\author{
* Correspondence: christina.wy. \\ wong@polyu.edu.hk \\ 'Shipping Research Centre, The \\ Hong Kong Polytechnic University, \\ Hung Hom, Hong Kong, China \\ Full list of author information is \\ available at the end of the article
}

\begin{abstract}
Both trade and transport logistics activities have impressively flourished among the Association of Southeast Asian Nations (ASEAN) countries over the past decades. Based on these observations, this paper conjectures that trade liberalization and transport logistics development are mutually reinforced. Elimination of internal tariff in the free trade area facilitates trade thereby increasing the demand for transport logistics. Transport logistics development generates spillover effect to promote trade with nonmembers. The findings of this paper indicate that a country's transport logistics development will bolster both of its regional and global trade development.
\end{abstract}

Keywords: Trade liberalization, Trade facilitation, Trade integration, Tariff, Intra-FTA trade, Extra-FTA trade, Transport logistics, ASEAN

\section{Introduction}

Relationship between transport logistics development and trade facilitation has received growing research attention in recent years (Dee et al. 2008; Portugal-Perez and Wilson 2012; Lun and Hoffmann 2016; Yap 2019) particularly under the new waves of economic integration through an emerging array of multilateral preferential trading arrangements such as the North American Free Trade Agreement and the Latin American Free Trade Association. There is a general belief that transport logistics development, such as improved physical infrastructure enabling faster delivery, and more-reliable product distribution network, will foster the flows of international trade (Brooks 2010; Hummels and Schaur 2013; Laird and Venables 2017; Wilson et al. 2004; Hausman et al. 2013; Hoffmann et al. 2017). Following this line of arguments, this paper proposes that increasing trade flows due to economic liberalization drives transport logistics development which in turns facilitates trade activities to a greater extent. We investigate the link between mutual causality of trade growth and transport logistics development in the context of the Association of Southeast Asian Nations (ASEAN) and seek to provide managerial and policy insights of the link for international logistics management.

ASEAN is one of the world's most dynamic and prosperous economic blocs. It was formed in the late 1960s by Indonesia, Malaysia, the Philippines, Singapore, and Thailand, with the initial membership continually expanded with the subsequent entry of Brunei, Vietnam, Laos, Myanmar, and Cambodia. These ten member countries 
constitute the ASEAN by the year 1999. According to the World Bank (2018), the combined gross domestic product (GDP) of ASEAN exceeded US\$ 2.77 trillion in 2017, contributing to $3.4 \%$ of the world's GDP.

The phenomenal economic development of ASEAN over the past decades contributes to the expansion of the intra-regional trade. Cooperation in regional trade facilitation is a vital segment of ASEAN's declared common targets (Hew 2008). ASEAN free trade area (AFTA) agreement, which was officially endorsed in 1992, is a multinational cooperative arrangement that seeks to enhance ASEAN's strength as a production base in the global market. AFTA calls for the reduction or elimination of tariff rates on intra-ASEAN trade in processed agricultural products, manufactures, and capital goods through the Common Effective Preferential Tariff (CEPT) scheme under which each country agrees to lower tariffs within the range of $5 \%$ in the given time frame (Wignaraja 2015). At the forefront in promoting and practicing regional free trade development, ASEAN Economic Community (AEC) was formally established by end of 2015, targeting to remove both intra-regional tariff and formal services sector restrictions, reduce trade costs by simplifying cross-border processes, improve infrastructures networks, and enhance transportation connectivity (ASEAN Secretariat 2017). It is widely recognized that AFTA enables ASEAN to be transformed from a loose organization into an institutionalized economic bloc (Shaun 2003).

Since international trade depends largely on the facilitation by providers of transport logistics service to complete the economic transactions through physical delivery, increasing trade flows are associated with the wider and improved logistical connectivity among the involved countries (Lun and Hoffmann 2016; Munim and Schramm 2018). In particular, transportation costs alter the relative prices of cargoes and hence restrict competition and distort trade flows (Hummels and Schaur 2013). While ASEAN has been instrumental in eliminating tariffs, it has to struggle with transport logistics inefficiencies in many cases. In the 2007 ASEAN Summit, the ASEAN leaders reached an agreement that transport logistics needs to be developed in pace with the international trade demands and identified as a priority sector for expediting the regional economic integration (Banomyong et al. 2008; Shaun 2003; Liu et al. 2018). With the aim to promote regional transport logistics services through facilitation measures and liberalization, the Roadmap for the Integration of Transport logistics Services was also endorsed in the year of 2007 (ASEAN Secretariat 2008). Despite there is room for ASEAN member countries to improve and enhance the competitiveness and capability in the aspect of transport logistics services, multi-modal transport infrastructures, and human resources, the obstacles in the liberalization of the maritime freight sector have been mostly eliminated (Tongzon 2011; Tongzon and Cheong 2014). Recently, ASEAN has made remarkable progress in transport logistics: the time to export has shortened by 6.2 days on average from 2007 to 2014 where the container port traffic within the ASEAN countries has increased by 31.3 million TEUs from 2007 to 2016. The Logistics Performance Index report also indicates that the average score of ASEAN member countries have improved by 3\% from 2007 to 2016 (Arvis et al. 2016).

Looking ahead, ASEAN's economic rise depends not only on regional trade liberalization but also on its openness to the world economy. The expansion of trade activities benefits the ASEAN countries by scale economies in production due to specialization in terms of their comparative advantages in productive activities. The 
need for greater economic coordination and cooperation to manage and facilitate regional economic integration is widely recognized among ASEAN countries. With a view to widen its economic contacts, ASEAN has made great strides in promoting trade partnership with other countries in the Asia Pacific region. For example, ASEAN signed a free trade agreement with Australia and New Zealand to coordinate economic and trade cooperation in 2009, established the "ASEAN +3 " framework of free trade initiative with China, Japan, and South Korea in 2010, and joined in economic collaboration under the Trans-Pacific Partnership which is proposed by the United States in 2011. More recently, ASEAN has launched the negotiation of free trade separately with its six major trading partners - Australia, China, India, Japan, New Zealand, and South Korea - for the Regional Comprehensive Economic Partnership (Lim 2009; Nesadurai and Djiwandono 2009). An informal meeting between ASEAN and European Cooperation Organisation was also held in 2016 to reinvigorate the collaboration in small and medium enterprises (SMEs) development and trade (ASEAN Secretariat 2016). These developments highlight the pledge of ASEAN to strengthen its trade ties with rest of the world.

As in the case of ASEAN, a country's trade liberalization can lead to a chain reaction, in the sense that it will trigger the mutual reinforcement between trade growth and transport logistics development. Specifically, regional trade liberalization facilitates cargo trade within the region, which requires the supports of well-constructed transport infrastructures, technologies, and services. The subsequent logistical improvement generates a diffusion effect to foster trade activities between the region and the rest of the world. While previous studies focus on examining the effect of transport logistics on international trade (Hausman 2004; Hausman et al. 2013; Hummels 2007), we also examine the impact of international trade on transport logistics, suggesting that the formation of free trade area (FTA) is beneficial not only for trade activities between the member countries, but also trade flows with rest of the world.

This paper is based on our working paper (Lai et al. 2015), which was the first paper at that time raising the theorectical hypotheses and testing them with data collected from ASEAN countries. We employ macro-level data studying the links between internal tariff rates, international trade, and transport logistics development concerning ASEAN countries. To begin with, we examine whether tariff reduction among ASEAN member countries has significantly raised intra-ASEAN trade, and then determine whether the transport logistics development acts as a bridge between the intra-ASEAN trade growth and extra-ASEAN trade growth. As the study scope covers cross-border transport logistics, we measure the transport logistics development by two transport modes, that is, maritime and air.

\section{Hypothesis development}

International trade involves exchange of goods and services between countries beneficial for the participating entities. Related theories such as the absolute advantage (Smith 1776) and comparative advantage (Ricardo 1817) highlight the importance of international trade to improve efficient use of resources and hence facilitate specialization in areas with competitive strength. In the international markets, the regional free trade agreement is a widely used means of economic integration (Krugman 2015). The key feature of FTA is that all member countries are mandated to remove tariff rates on each other's products but retain their independence in making 
trade policies with nonmembers (Appleyard et al. 2001). Since the FTA formation implies differential treatments for the member countries as opposed to nonmembers, it will lead to two possible consequences, namely trade creation effect and trade diversion effect (Viner 1950). Trade creation occurs when the FTA formation enables one member country to import goods from another member country which has comparative advantage in producing the goods more efficiently. Comparatively, trade diversion refers to the process of shifting importing patterns from a cost-efficient producer outside the FTA to a less-efficient producer in the FTA to enjoy zero or low tariffs. In other words, economic regionalism tend toward protectionist blocs (Lim 2009); this redirection of trade flows will distort the resources allocation and result in efficiency loss (Schiff and Winters 2003).

The effect of trade creation and trade diversion due to economic integration has been studied extensively in literature. How the formation of ASEAN Free Trade Area (AFTA) influences the imports between Indonesia and other ASEAN countries was examined by Ramasamy (1994), where this study confirmed the trade creation effect within the region. Increasing investment volume is considered an important part of the pre-implementation stage of trade agreements (Freund and Mclaren 1999). The evidence of increasing trade flow at the initial stage of implementing North American Free Trade Agreement was also identified by Kose et al. (2004). Hapsari and Mangunsong (2006) found increased bilateral exports of the first five ASEAN member countries after the tariff reduction. They also observed the effect of both trade creation and trade diversion with evidence to show shifting trade from the rest of the world ("extra-FTA trade") to intra-FTA trade. By adopting the gravity model, Magee (2008) studied the data of bilateral trade flows among 133 countries from 1980 to 1998 and found that economic integration increased trade flows, even though there was trade diversion effect resulting from intra-FTA trade replacing extra-FTA trade, the overall trade creation effect is stronger than trade diversion. The study conducted by Lee et al. (2011) on the effect of formation of FTA between Taiwan and China confirmed the trade creation effect resulting from the increase in seaborne cargo volumes. By adopting the Global Trade Analysis Project model, Lee et al. (2013) studied the impact of development in Korean FTAs on international cargo flows and found significant increase in seaborne trade volumes. Using the data collected from AFTA, Okabe and Urata (2014) also confirmed the trade creation effect due to growing volume of imports and exports after eliminating the tariff. The relationship between AFTA and immediate trade creation effect was also verified with the manufacturing trade data of eight ASEAN member countries (Bary 2015).

Multilateral free trade agreement among the involved countries requires removal of tariff-based barriers within that economic region. The FTA formation allows countries with small domestic market to enlarge their market size, allowing more-efficient producers entry into countries where their prices had been inflated by duties (Lim 2009; Lee and Lee 2012). Removing internal tariffs generates two benefits to intra-FTA trade. First, the prices of traded goods are lowered, leading to the increased consumer surplus (Eaton and Kortum 2003). Second, a member country can import cheaper goods from another member country rather than producing them domestically, which creates new flows of cross-border trade (Schiff and Winters 2003). Resources becoming accessible to member countries improves their capabilities to participate in trade activities through which 
further intra-FTA trade can be promoted. Member countries can import low-priced commodities from other members to replenish insufficient domestic production, as the price of the traded goods decreased due to tariff removal, mitigating the distortion between consumption and production and contributing to additional economic gains (Krugman 2015). In contributing to economic integration, FTA promotes efficient use of resources within the region. Based on the above discussions, we put forward the following hypothesis.

\section{$\mathrm{H} 1$ : there is a negative correlation between a member country's tariff rates offered to} other member countries and its intra-FTA trade. Specifically, a fall in the internal tariff rates by a member country will increase its intra-FTA trade

We contribute knowledge to the literature by examining the role of transport logistics development in international trade activities. Transport logistics connects economic exchanges for international trade as it handles the physical movements of traded goods among involved parties through the services provided to link up production and consumption (Christopher 2016). When a company makes sourcing decisions for import, it needs to consider the "total landed costs" which include freight, insurance, customs duty, documentation, and inventory expenses (Hausman et al. 2013), all of which are part of transport logistics activities. The extent to which a country can expand for international trade depends on the capability of shipping its imports and exports at the right amount of the right product at the right place at the right time in the right condition at the right price with the right information to satisfy the overseas markets fully, reflecting the importance of the seven "rights" principles of transport logistics management (Lai and Cheng 2009). As an important part of trade cost, shipping cost influences international trade volume due to the need for physical product transfer by the involved exchange parties to complete the economic transaction. A country's trade activities can benefit from its capability in transport logistics by lowering shipping related costs. High shipping costs discourage a country's trade activities in the form of trade barrier hampering product flows as evidenced in part of the Middle East region (Devlin and Lee 2005).

There are two types of barriers that restrict international trade - tariff-based barriers, and non-tariff trade barriers (NTBs). According to Anderson and van Wincoop (2004), the artificial tariff-based barriers account for about $10-20 \%$ of a traded good's ex-factory price in the developed world. Brooks (2010) estimated that the proportion tends to be higher in the developing countries. The NTBs, on the other hand, are attributed to a wide range of hurdles including import quota, export subsidies, foreign exchange control, and most saliently, transport logistics inefficiencies (Appleyard et al. 2001). Such inefficiencies will harm the competitiveness of businesses through incurring longer transit time (Djankov et al. 2010; Ferrari et al. 2010; Evans and Harrigan 2005; Hausman et al. 2013; Hummels and Schaur 2013; Nordas et al. 2006), higher expenses on handling and distribution (Hausman 2004), and insecurity in inventory and delivery (Carruthers et al. 2004; Nordas et al. 2006). Many empirical studies examining customs data suggests that trade barriers attributable to cross-border transportation costs can be great, not less than those of tariff-based barriers (Limao and Venables 2001; Hummels 2007). While the tariff-based trade barriers are being lowered or eliminated, the rising contribution of transport 
logistics inefficiencies to total costs of intra-FTA trade turns out to be a more urgent concern for member countries for trade development. The increasing demands for intra-FTA trade require each member country to upgrade transport logistics capability and performance. A highly-developed transport logistics sector is characterized by excellent physical transport infrastructures (for example, port construction and maintenance, and vessel building and modernization), the related technological supports (for example, web-based tracing and tracking, containerization, and intermodal transport), and quality services (for example, administrative management, insurance, consolidation, warehousing, and delivery). A number of studies have found value of quality port infrastructure to national economy (Ferrari et al. 2010; Bottasso et al. 2014; Munim and Schramm 2018). Sound physical infrastructure or network of transport logistics as well as technological advancement adopted in the transport logistics system are beneficial for cargo flows. In response to trade liberalization by the FTA formation, the transport logistics sector of the member countries will improve in development subsequent to the increase in intra-FTA trade flows.

\section{H2: there is a positive correlation between a member country's intra-FTA trade and its performance of transport logistics. Specifically, an increase in intra-FTA trade of a member country will improve its performance of transport logistics}

Transport logistics development in support of intra-FTA trade growth tends to generate beneficial spillovers effect to accelerate extra-FTA trade. A country's transport logistics performance with respect to physical transport infrastructures, technological supports, and related services will influence all of its trading activities (Korinek and Sourdin 2011). First, improvement in physical transport infrastructures will strengthen a country's accessibility to its global trading partners (Limao and Venables 2001; Wood et al. 2003). Additional access to the international market can be facilitated by the investment and improvement in transport sector (Findlay 2007; Wong et al. 2012b). The infrastructure investments improve and expand linkages to the global supply chain (Wong et al. 2012a; Lun et al. 2011; Wong et al. 2013; Wong et al. 2017). For example, a newly-built large container port by a member country tends to accommodate larger and more vessels, and hence attracts cargo flows from member countries as well as other nonmembers. Second, innovation and application of modern transport logistics technologies (for example, automation and radio frequency identification) enhance a country's capability of processing information and handling traded goods in timely and reliable manner (Memedovic et al. 2008; Ustundag and Tanyas 2009; Wong et al. 2013). The technological progress will help the trading companies to smooth their supply chains by lowering operations costs and saving time irrespective of their product importing origin or exporting destination. For instance, an effective border management system can fasten the clearance time and lessen the chance for delay in transporting goods, shortening the lead-time along the supply chain. Third, transport logistics services are instrumental in supporting a country's global trade activities which rely on warehousing, product channel availability, packaging and labeling, reliability of shipping, and administrative management by port terminals and customs authorities (Gupta et al. 2011; Lai 2004). Container inspections, berth planning, customs clearance, and regulatory environment are all vital in determining the efficiency of port throughput (Clark et al. 2004; Lun and Cariou 2009; Wilson et al. 2004). Effective cargo management in container 
terminals can ease congestion problems for traded goods on international transit at ports (Lun and Cariou 2009). Export growth can be promoted by improving transport efficiency via investments in physical infrastructure (Portugal-Perez and Wilson 2012). Hwang et al. (2017) have also identified the contribution of logistics industry to national economic growth. By studying the Brazilian exports, Bottasso et al. (2018) found positive association between port infrastructures and export volume and that the development of other types of transport infrastructure can reinforce this relationship. In general, since the physical infrastructures and the related technologies and services of a country are publicly accessible by all of its trading businesses, the transport logistics development targeting intra-FTA trade growth can promote the flows of extra-FTA trade. Accordingly, we hypothesize that.

H3: there is a positive correlation between a member country's transport logistics performance and its extra-FTA trade. Specifically, an increase in transport logistics performance by a member country will increase its extra-FTA trade

In Fig. 1, we present a path diagram which illustrates the mechanism that trade liberalization will trigger the mutual reinforcement between trade growth and transport logistics development. We argue that FTA formation spurs the intra-FTA trade growth which increases demands for transport logistics development, and the developed transport logistics in turns facilitates extra-FTA trade. There are two key implications from this chain relation. First, tariff reduction and transport logistics development are complementary in expediting international trade growth. As trade liberalization lowers the level of trade protection by eliminating artificial tariff-based barriers, transport logistics inefficiencies especially in less-developed member countries are the bottleneck in stifling international trade activities. Promotion of international trade hence requires a country to both develop transport logistics and lower tariff rates so that neither barrier becomes a handicap. Second, trade liberalization will generate "double-dividend" to a country. The direct benefit is the efficiency gain arising from scale economy and specialization contributed by comparative advantages in productive activities, which echoes the trade creation effect. In other words, the elimination of tariff-based barriers on inner borders of the member countries leads to a fall in the prices of traded products, thereby creating trade flows within the FTA. The indirect benefit comes from the extra-FTA trade growth driven by the derived transport logistics development. If this trade creation effect dominates the trade diversion effect, we would expect the growth of extra-FTA trade.

\section{Research method and data}

We empirically investigate our three hypotheses in the context of the ASEAN countries and specifically on $(i)$ the lag effect of CEPT rates on intra-ASEAN trade, (ii) the lag

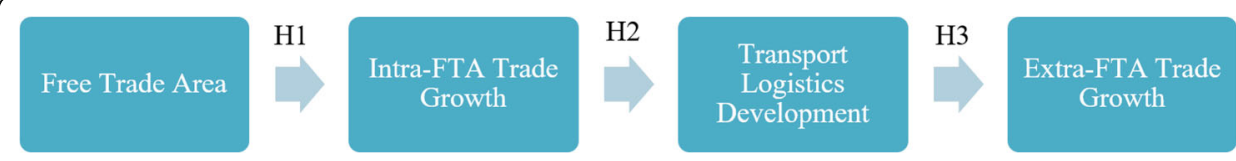

Fig. 1 Intra-FTA trade, Transport Logistics Development, and Extra-FTA trade: A Chain Effect 
effect of intra-ASEAN trade on a country's transport logistics development, and (iii) the lag effect of transport logistics development on a country's extra-ASEAN trade.

Our regression analysis requires the data on CEPT rates, intra-ASEAN trade, extra-ASEAN trade, and some transport logistics measurements of each ASEAN member country. Data on the country-level annual CEPT rates are found in ASEAN Secretariat; note that the time span for CEPT rates is the period 1996-2003, subject to limited data availability. Data on each country's international trade with different partner countries in each year can be found in the Directory of Trade Statistics by the International Monetary Fund. For each member country, the intra-ASEAN trade is a sum of its exports to other members and the exports the other way around. Subtracting a country's intra-ASEAN trade from its total trade obtains its extra-ASEAN trade.

We proceed to discuss a variety of quantitative measures for evaluating a country's transport logistics development. As international trade involves cross-border transport logistics activities, maritime and air transportation are our focus considering their cargo volume and value handled by these two transportation modes respectively. International maritime shipping is a crucial segment in the global freight transport system that comprises sea and coastal routes and inland waterways. The inbound and outbound freight flows through seaports could be considered as a "trip-generator" for international trade (Corbett and Winebrake 2009). Maritime transportation constitutes the dominant means in international trade since more than $80 \%$ of cargos marketed worldwide are carried by sea (Sida 2009). On one hand, sea transport is of particular importance for intra-ASEAN trade because the member countries are separated by seas rather than connected with landmass. On the other hand, ASEAN has one of the busiest shipping lanes because of its excellent geographic location on the Strait of Malacca which links the Pacific Ocean and the Indian Ocean (Song 2015).

We measure the maritime shipping performance by employing six proxies as follows.

LP1: Liner shipping connectivity index

LP2: Container port traffic

LP3: International sea cargo throughput

LP4: International sea container throughput

LP5: Number of international container vessel fleet

LP6: Volume of international container vessel fleet

Moreover, air transport is another major way of physical movement of goods between countries. Having experienced fastest growth over the decades, air transport by far becomes an economic conduit for international trade and a prevailing component of international transport logistics. For example, Singapore has been positioned as one of the key hubs of international air traffic flows in Asia (Matsumoto 2007). An interconnected and efficient air transport system will help accelerate trade growth and reduce transaction costs in trade (Li 1998). Air connectivity is an important enabler for trade in the increasingly globalized marketplace (Mcquaid et al. 2004; Smyth et al. 2013). We propose two proxies for evaluating a country's air transport performance. 


\section{LP7: Air freight}

LP8: International air cargo unloaded volume

Table 1 summarizes the definition and explanations for each of the aforementioned eight measurements of a country's transport logistics performance in terms of air and maritime transport. We collect the data on these measurements from the World Bank, UNCTAD, and ASEAN Statistics of Transportation; the exact data source of each measurement is listed in the last column of Table 1.

\section{Hypothesis testing and results}

We proceed to test each of the three hypotheses by employing longitudinal analysis with fixed-effect estimation method with data from ASEAN countries. Throughout the testing, we adopt the lag structure of regression model, that is, one-year lag for the explanatory variable. This lag structure serves two purposes. Firstly, we allow for time lag of government policy and the responding time of the market. For instance, there

Table 1 Definition and Data Description of Measurements for Transport logistics Performance

\begin{tabular}{|c|c|c|c|c|}
\hline Mode & Measure & Description & Unit & $\begin{array}{l}\text { Data Period \& } \\
\text { Source }\end{array}$ \\
\hline \multirow[t]{6}{*}{$\begin{array}{l}\text { Maritime } \\
\text { Transport }\end{array}$} & $\begin{array}{l}\text { LP1: Liner Shipping } \\
\text { Connectivity } \\
\text { Index }\end{array}$ & $\begin{array}{l}\text { An index captures how well countries are } \\
\text { connected to the global shipping network } \\
\text { and reflects the strategies of container } \\
\text { shipping lines seeking to maximize revenue } \\
\text { through market coverage. It is computed } \\
\text { based on number of ships, their container- } \\
\text { carrying capacity, average and maximum } \\
\text { vessel size, number of services, and number } \\
\text { of companies that deploy container ships } \\
\text { in ports. }\end{array}$ & - & $\begin{array}{l}\text { 2004-2014: } \\
\text { UNCTAD }\end{array}$ \\
\hline & $\begin{array}{l}\text { LP2: } \\
\text { Container Port Traffic }\end{array}$ & $\begin{array}{l}\text { The flow of containers in } 20-\mathrm{ft} \text { equivalent } \\
\text { units from land to sea transport modes, and } \\
\text { vice versa, including coastal shipping and } \\
\text { international journeys. Transshipment traffic is } \\
\text { counted as two lifts at the intermediate port } \\
\text { and includes empty units. }\end{array}$ & TEUs & $\begin{array}{l}\text { 2000-2013: The } \\
\text { World Bank }\end{array}$ \\
\hline & $\begin{array}{l}\text { LP3: } \\
\text { International } \\
\text { Sea Cargo } \\
\text { Throughput }\end{array}$ & $\begin{array}{l}\text { The average quantity of cargo that pass } \\
\text { through a port from arrival at the port to } \\
\text { loading onto a ship, or from the discharge } \\
\text { from a ship to clearance from the port. }\end{array}$ & ton & $\begin{array}{l}\text { 2004-2012: ASEAN } \\
\text { Statistics of } \\
\text { Transportation }\end{array}$ \\
\hline & $\begin{array}{l}\text { LP4: } \\
\text { International } \\
\text { Sea Container } \\
\text { Throughput }\end{array}$ & $\begin{array}{l}\text { The average quantity of cargo carried by } \\
\text { containers, which reflects the fact that } \\
\text { international trade is primarily handled } \\
\text { by containers. }\end{array}$ & TEUs & $\begin{array}{l}\text { 2004-2012: ASEAN } \\
\text { Statistics of } \\
\text { Transportation }\end{array}$ \\
\hline & $\begin{array}{l}\text { LP5: Number of } \\
\text { International } \\
\text { Container } \\
\text { Vessel Fleet }\end{array}$ & $\begin{array}{l}\text { The number of a variety of operating } \\
\text { container ships. }\end{array}$ & count & $\begin{array}{l}\text { 2004-2012: ASEAN } \\
\text { Statistics of } \\
\text { Transportation }\end{array}$ \\
\hline & $\begin{array}{l}\text { LP6: Volume of } \\
\text { International } \\
\text { Container } \\
\text { Vessel Fleet }\end{array}$ & $\begin{array}{l}\text { Gross tonnage of all container ships, } \\
\text { as measured in TEUs. }\end{array}$ & ton & $\begin{array}{l}\text { 2004-2012: ASEAN } \\
\text { Statistics of } \\
\text { Transportation }\end{array}$ \\
\hline \multirow[t]{2}{*}{$\begin{array}{l}\text { Air } \\
\text { Transport }\end{array}$} & $\begin{array}{l}\text { LP7: Air } \\
\text { Freight }\end{array}$ & $\begin{array}{l}\text { The volume of freight, express, and } \\
\text { diplomatic bags carried on each flight stage } \\
\text { (aircraft operation from takeoff to } \\
\text { next landing) }\end{array}$ & $\begin{array}{l}\text { ton- } \\
\text { kilometer }\end{array}$ & $\begin{array}{l}\text { 2000-2013: The } \\
\text { World Bank }\end{array}$ \\
\hline & $\begin{array}{l}\text { LP8: International Air } \\
\text { Cargo Unloaded } \\
\text { Volume }\end{array}$ & $\begin{array}{l}\text { Gross cargo unloaded by unit load devices } \\
\text { from aircrafts. }\end{array}$ & ton & $\begin{array}{l}\text { 2004-2012: ASEAN } \\
\text { Statistics of } \\
\text { Transportation }\end{array}$ \\
\hline
\end{tabular}


may be a time-lag between government's implementation of tariff rates and trading firms' decision on exports/imports, and it takes some time to develop transport logistics (for example, infrastructure construction and new technology adoption (Lai et al. 2006, La Londe and Powers 1993)) in response to intra-FTA trade growth. Secondly, the lag structure enables us to avoid the estimation bias caused by the possible reverse causality, for example, the impact of trade demand on government's trade policy making, the impact of transport logistics development on intra-FTA trade growth, and the impact of extra-ASEAN trade growth on transport logistics development.

\section{Testing of hypothesis 1}

To examine the relationship between CEPT rates on intra-ASEAN trade growth, we regress the natural logarithm of intra-ASEAN trade on the one-year lagging CEPT rates across the ASEAN countries. We also control the potential intervening variables that affect a country's international trade, such as the one-year lagging national annual GDP per capita and the one-year lagging civil liberties (CL). GDP per capita, which tends to be strongly related with a country's international trade (Dollar and Kraay 2003), is expected to be a relevant control variable: a richer country has higher production capability and higher demands for imported goods. In addition, as Aidt and Gassebner (2010) shows, CL is a main driver for international trade growth. As political freedom can be positively associated with economic freedom, and it promotes economic prosperity and trade between countries as democracy implies better public governance (Balding 2011). The economic stance of a country can be shaped by its government's commitment to develop and implement trade policy, which in turn affects the export and import trade volume. Data on countrywide GDP per capita are collected from the World Bank, while data on CL are obtained from Freedom House.

Table 2 reports the regression results of Hypothesis 1. Model 1 presents our finding about the simple log-liner relationship between intra-ASEAN trade and one-year lagging CEPT rates. The result shows that this negative correlation is statistically significant at the 0.01 level. Moreover, our estimation achieves high goodness-of-fit as both $R^{2}$ and adjusted $R^{2}$ are above 0.98 , which implies that the internal tariff rates among the ASEAN member countries contribute high explanatory power to intra-ASEAN trade. Model 1a re-examines this relationship by incorporating the two control variables, namely GDP per capita and CL, which are also in one-year lag. It shows that the inclusion of control variables has slight influence on the regression outcome: the goodness of fit of the specification sustains, and the statistical significance of the key estimate reaches 0.015 level. Overall, the estimation result is robust and consistent with Hypothesis 1: as the ASEAN countries were creating the AFTA by lowering the internal tariff rates, their trade with each other members tends to rise substantially.

Table 2 Regression Results of Hypothesis 1

\begin{tabular}{lllllll}
\hline Model & $\begin{array}{l}\text { Dependent } \\
\text { Variable }\end{array}$ & Independent Variable & Control Variable & $R^{2}$ & Adjusted $R^{2}$ & $p$-value \\
\hline 1 & IT & CEPT & - & 0.988 & 0.983 & 0.003 \\
$1 \mathrm{a}$ & IT & CEPT & GDP per capita, CL & 0.989 & 0.983 & 0.015 \\
\hline
\end{tabular}

Notes: IT Denotes the natural logarithm of intra-ASEAN trade, CEPT Denotes intra-ASEAN tariff rate, CL Denotes civil liberties; explanatory and control variables are in one-year lag 


\section{Testing of hypothesis 2}

To examine the influence of intra-ASEAN trade on transport logistics development, we conduct a simple linear regression of the air and maritime transport performance against the one-year lagging intra-ASEAN trade. Since ASEAN was officially established as an economic bloc with ten member countries in 1999, we conduct the regression analysis based on the sample spanning from 2000 onward. Moreover, we include the control variable, the one-year lagging GDP per capita, in our estimations because a country's air and maritime transport performance is considered positively associated with its income level (Clark et al. 2004).

Table 3 summarizes the estimation results of Hypothesis 2. For models 2.1 through 2.6a where transport logistics is measured by the variables relating to maritime shipping, we find that an ASEAN country's trade with other ASEAN countries is significantly and positively associated with its performance of maritime transport. All the estimates achieve a statistical significance at the 0.01 level. For models 2.7 through 2.8a where transport logistics is measured by the variables relating to air transport, it appears that an ASEAN country's trade with other ASEAN countries is significantly and positively correlated with its aviation transport development. All the estimates have achieved a statistical significance level of at least 0.05 except for those in model 2.8a. Comparing the estimations between 2.8 and 2.8a, we suggest that the statistical insignificance of the effect of intra-ASEAN trade on international air cargo unloaded volume arise from the intervention by GDP per capita. One possible reason is as follows: most of the intra-ASEAN trade involve low-value goods that rely much on maritime transport rather than air transport; however, most of imports by air involve valuable goods that require fast delivery, and hence are likely to be sourced from the developed world as domestic citizens become richer. In general, we show with empirical evidence that an ASEAN country's trade with members will foster air and maritime transport performance in the following year, which accords with Hypothesis 2.

Table 3 Regression Results of Hypothesis 2

\begin{tabular}{|c|c|c|c|c|c|c|}
\hline Model & Dependent Variable & Independent Variable & Control Variable & $R^{2}$ & Adjusted $R^{2}$ & $p$-value \\
\hline 2.1 & LP1 & IT & - & 0.974 & 0.968 & 0.000 \\
\hline $2.1 \mathrm{a}$ & LP1 & IT & GDP per capita & 0.972 & 0.964 & 0.001 \\
\hline 2.2 & LP2 & IT & - & 0.975 & 0.968 & 0.000 \\
\hline $2.2 \mathrm{a}$ & LP2 & IT & GDP per capita & 0.978 & 0.971 & 0.000 \\
\hline 2.3 & LP3 & IT & - & 0.996 & 0.995 & 0.000 \\
\hline $2.3 a$ & LP3 & IT & GDP per capita & 0.996 & 0.994 & 0.000 \\
\hline 2.4 & LP4 & IT & - & 0.990 & 0.987 & 0.000 \\
\hline $2.4 a$ & LP4 & IT & GDP per capita & 0.992 & 0.989 & 0.006 \\
\hline 2.5 & LP5 & IT & - & 0.985 & 0.980 & 0.000 \\
\hline $2.5 a$ & LP5 & IT & GDP per capita & 0.985 & 0.978 & 0.000 \\
\hline 2.6 & LP6 & IT & - & 0.985 & 0.979 & 0.000 \\
\hline $2.6 a$ & LP6 & IT & GDP per capita & 0.987 & 0.980 & 0.006 \\
\hline 2.7 & LP7 & IT & - & 0.985 & 0.986 & 0.001 \\
\hline $2.7 a$ & LP7 & IT & GDP per capita & 0.989 & 0.986 & 0.001 \\
\hline 2.8 & LP8 & IT & - & 0.992 & 0.990 & 0.046 \\
\hline $2.8 a$ & LP8 & IT & GDP per capita & 0.992 & 0.990 & 0.128 \\
\hline
\end{tabular}

Notes: IT Denotes intra-ASEAN trade; explanatory and control variables are in one-year lag 


\section{Testing of hypothesis 3}

To test the effect of transport logistics development on extra-ASEAN trade, we perform a simple linear regression of the extra-ASEAN trade against the one-year lagging air and maritime transport performance. Similar to the testing of Hypothesis 1, we add the one-year lagging GDP per capita and the one-year lagging CL as a potential intervening variable for trade growth. Similar to the testing of Hypothesis 2, we analyze the hypothesized effect using the sample covering the period from 2000 onward.

Table 4 reports the estimated effect of air and maritime transport performance on extra-ASEAN trade. Clearly, all the regression estimations display a statistical significance at the 0.01 level except for the models 3.6 and 3.6a where LP6 (volume of international container vessel fleet) acts as the proxy for transport logistics. It is shown that LP6 will influence a country's extra-ASEAN trade with statistical significance at 0.1 level; and this effect will only diminish with the inclusion of the control variable. Besides, in all the specifications, the goodness-of-fit seems to increase upon the inclusion of control variables, which justifies the need to include one-year lagging GDP per capita and one-year lagging $\mathrm{CL}$ in the estimations. In general, we present supporting evidence for Hypothesis 3; that is, transport by air and maritime has facilitated the trade between ASEAN and outside countries.

\section{Conclusions}

\section{Theoretical implications}

The past few decades has witnessed rapid economic growth of the ten ASEAN member countries and their deeper economic integration with each other through trade and transport logistics connectivity. This paper puts forward a theoretical conjecture about the mutual reinforcement between trade growth and transport logistics development.

Table 4 Regression Results of Hypothesis 3

\begin{tabular}{|c|c|c|c|c|c|c|}
\hline Model & Dependent Variable & Independent Variable & Control Variable & $R^{2}$ & Adjusted $R^{2}$ & $p$-value \\
\hline 3.1 & ET & LP1 & - & 0.967 & 0.959 & 0.000 \\
\hline $3.1 \mathrm{a}$ & ET & LP1 & GDP per capita, CL & 0.968 & 0.958 & 0.000 \\
\hline 3.2 & ET & LP2 & - & 0.956 & 0.944 & 0.000 \\
\hline $3.2 \mathrm{a}$ & ET & LP2 & GDP per capita, CL & 0.962 & 0.951 & 0.015 \\
\hline 3.3 & ET & LP3 & - & 0.977 & 0.970 & 0.000 \\
\hline $3.3 a$ & ET & LP3 & GDP per capita, CL & 0.978 & 0.970 & 0.000 \\
\hline 3.4 & ET & LP4 & - & 0.972 & 0.964 & 0.000 \\
\hline $3.4 a$ & ET & LP4 & GDP per capita, CL & 0.974 & 0.963 & 0.001 \\
\hline 3.5 & ET & LP5 & - & 0.944 & 0.925 & 0.003 \\
\hline $3.5 a$ & ET & LP5 & GDP per capita, CL & 0.944 & 0.919 & 0.007 \\
\hline 3.6 & ET & LP6 & - & 0.945 & 0.921 & 0.104 \\
\hline $3.6 a$ & ET & LP6 & GDP per capita, CL & 0.966 & 0.947 & 0.991 \\
\hline 3.7 & ET & LP7 & - & 0.914 & 0.897 & 0.000 \\
\hline $3.7 a$ & ET & LP7 & GDP per capita, CL & 0.926 & 0.909 & 0.000 \\
\hline 3.8 & ET & LP8 & - & 0.966 & 0.956 & 0.000 \\
\hline $3.8 \mathrm{a}$ & ET & LP8 & GDP per capita, CL & 0.972 & 0.961 & 0.000 \\
\hline
\end{tabular}

Notes: ET Denotes extra-ASEAN trade, CL Denotes civil liberties; explanatory independent and control variables are in one-year lag 
We consider the international transport logistics inefficiency as a kind of NTBs restraining international trade. It is therefore suggested that transport logistics development will complement for regional tariff reduction in fostering a country's trade activities as improvements in various activities facilitating trade are resulted from the increase in intra-FTA trade; for example, customs procedures at borders between member countries can be minimized. Such act can shorten the time at customs and/or border clearance thus improve the transport logistics efficiency. We also consider a country's maritime and air transport logistics as "public goods" visible to all other trading partners. In that case, a country's transport logistics development induced by the regional FTA formation will generate spillovers effect to support its extra-FTA trade growth. If positive spillovers are strong enough to offset the missing trade flows by trade diversion effect, the extra-FTA trade is expected to increase.

To support our conjectures, we conduct regression analysis by using the secondary macro data from the ASEAN countries. Our analysis has three main empirical findings. First, a fall in the internal tariffs will increase the intra-ASEAN trade. Second, the member countries will develop their transport by maritime and air in addition to the reduction of tariff-based barrier resulting from the formation of FTA, so as to facilitate intra-ASEAN trade. Finally, the development of transport by maritime and air will positively affect trade with the world outside ASEAN, which is consistent with the finding of the existing literature such as Clark et al. (2004) and Hausman et al. (2013) among others.

\section{Practical implications}

Our empirical findings shed some lights on managerial strategies for both trading and transport logistics firms. The FTA formation offers enormous business opportunities for international trade. The more open trade environment enables exporters to enhance their competitiveness and establish new trading connections. With the leverage of transport logistics development that reduces the NTBs for any potential business partners, trading firms may also explore prospective suppliers and customers outside the FTA. Moreover, transport logistics firms should respond to the regional trade liberalization by upgrading their capabilities of energizing the global movement of goods. They should also seize the opportunity to enrich knowledge and experience in sea and air transport connections, transportation, forwarding, warehouse, and courier services. Transport logistics development will benefit trade growth in the expanding markets and the benefits will be amplified under global trade growth which in turns prompts further transport logistics development.

Yet, a country's international trade is dependent not only on what has been done in trading and transport logistics firms, but also on the government role in policy making. The FTA formation is instrumental for reducing tariff-based barriers to secure preferential access for businesses in different countries to enter each other's market. In view of the growing trend for globalization of market and production activities, the trade barriers caused by prevailing transport logistics inefficiencies should not be ignored by policy makers (Mann 2012). Inefficient transport planning can lead to bottlenecks with significant negative economic consequences through congestion, late deliveries, and ultimately loss of businesses. Our study offers a macroeconomic perspective on the important role of developing transport logistics industry in trade facilitation. ASEAN leaders should be 
aware of the mutual reinforcement of trade growth and transport logistics that development in transportation is essential not only to support the increasing trade flows within ASEAN but also to bridge the AFTA formation to keep up with the rise in trade with the rest of the world. To leverage on transport logistics for continual trade growth, ASEAN leaders can embark on purposeful improvements in both physical and soft infrastructures. Being a region surrounded by waters, ASEAN is supposed to allocate adequate resources to construct and maintain its public shipping transport system and enhance its fleet modernization. ASEAN should also have commitment on the intangible "soft" infrastructures to ensure that operational needs are fulfilled. To be specific, government should take the lead in the aspects of human resources development, marketing promotion, regulatory transparency, electronic commerce, and supports for SMEs (Portugal-Perez and Wilson 2012). It is expected that economic boom brought about by growing trade and efficient transport logistics could help ASEAN better exercise economic influence on the globe.

Moreover, with the advances in trade cooperation among the ASEAN countries, international financial initiatives and institutions are expected to intensify investments in developing the trade-related public infrastructures. China is making efforts in orienting her world-class infrastructure industry to foreign markets. Starting in fall 2013, China has unveiled "One Belt One Road" policy which calls for the integration of Asia into a cohesive economic area through building infrastructure, increasing investment, and broadening trade; in particular, the Maritime Silk Road is a massive initiative that seeks to foster trade cooperation in Southeast Asia through the South China Sea, the South Pacific Ocean and the wider Indian Ocean area. For example, the proposed Kra Canal is considered as part of this Maritime Silk Road, which would turn the ASEAN into a hub for the development of the entire Pacific and Indian Ocean basins. Associated with this initiative is the establishment of the Asian Infrastructure Investment Bank (AIIB), a China-led multilateral fund that offers capital supports for developing countries to finance their transport networks and other infrastructure projects. These financial supports could help the ASEAN countries to gain from lower-cost upgrades of aging infrastructure. Two approved projects will be undertaken in Indonesia, namely Regional Infrastructure Development Fund Project and National Slum Upgrading Project, where both projects aim at aiding the development of urban transportation infrastructure. Furthermore, the National Road 13 Improvement and Maintenance Project with the objective to strengthen road design, road safety, and road conditions to fulfill the ASEAN standards are under planning in Lao People's Democratic Republic. The AIIB can also provide social safeguards that the development projects are designed and carried out in a sustainable manner.

\section{Limitations and future research}

In this study, we delve into two different transport modes, namely maritime and air, to measure a country's transport logistics performance. Note that a better proxy for transport logistics performance would be the score of transport logistics performance index (LPI) developed by the World Bank. LPI is an interactive benchmarking tool which measures a country's customs performance, infrastructure quality, ease of arranging shipments, quality of transport logistics services, tracking and tracing, and timeliness of shipments (Arvis et al. 2014). LPI is not employed in this study 
because its limited availability will drive the sample size of our regressions to be too small for analyses, which in turns leads to estimation bias. Future research - if conducted based on a sample of longer time series or greater coverage of countries - can utilize LPI to reexamine the mutual causality between trade growth and transport logistics development.

\begin{abstract}
Abbreviations
AEC: ASEAN Economic Community; AFTA: ASEAN Free Trade Area; AllB: Asian Infrastructure Investment Bank; ASEAN: Association of Southeast Asian Nations; CEPT: Common Effective Preferential Tariff; CL: Civil Liberties; FTA: Free Trade Area; GDP: Gross Domestic Product; LPI: Logistics Performance Index; NTBs: Non-tariff Trade Barriers; SMEs: Small and Medium Enterprises; UNCTAD: United Nations Conference on Trade and Development
\end{abstract}

\title{
Acknowledgements
}

The authors thank the editor and reviewers for their helpful comments and suggestions in the earlier versions of the paper. This research is partially supported by The Hong Kong Polytechnic University under grant no. 4-ZZGM and 1ZVLF.

\section{Funding}

This research did not receive any specific grant from funding agencies in the public, commercial, or not-for-profit sectors.

\section{Availability of data and materials}

The datasets generated and/or analysed during the current study are available in the ASEAN Secretariat at https:// asean.org/asean-economic-community/asean-free-trade-area-afta-council/other-documents/ and Direction of Trade Statistics by the International Monetary Fund at http://data.imf.org/?sk=9D6028D4-F14A-464C-A2F2-59B2CD424B85.

\section{Authors' contributions}

YP and KHL designed the research and analyzed the data. YP, YNEN and KHL wrote the paper. All authors read and approved the final manuscript.

\section{Competing interests}

The authors declare that they have no competing interests.

\section{Publisher's Note}

Springer Nature remains neutral with regard to jurisdictional claims in published maps and institutional affiliations.

\section{Author details}

${ }^{1}$ Shipping Research Centre, The Hong Kong Polytechnic University, Hung Hom, Hong Kong, China. ${ }^{2}$ School of Business, Macau University of Science and Technology, Taipa, Macau, China.

Received: 19 December 2018 Accepted: 27 March 2019

Published online: 26 April 2019

\section{References}

Aidt TS, Gassebner M (2010) Do autocratic states trade less? World Bank Econ Rev 24:38-76

Anderson E, van Wincoop E (2004) Trade costs. Journal of Economic Literature, 42(3), 691-751.

Appleyard DR, Field AJ, Cobb S (2001) International economics. McGraw-Hill//rwin, Boston

Arvis JF, Saslavsky D, Ojala L, Shepherd B, Busch C, Raj A, Naula T (2016) Connecting to compete: trade logistics in the global economy. World Bank, Washington DC

Arvis JF, Saslavsky D, Ojala L, Shepherd B, Busch C, Raj A (2014) Trade logistics in the global economy: the logistics performance index and its indicators. World Bank, Washington DC

ASEAN Secretariat (2008) Roadmap for the Integration of Logistics Services. Available: http://asean.org/asean-economiccommunity/sectoral-bodies-under-the-purview-of-aem/services/logistics-services/. Accessed 7 May 2018

ASEAN Secretariat (2016) Overview of ASEAN - Economic Cooperation Organization (ECO) Relation. Available: http://asean. org/asean/external-relations/international-regional-organisations/. Accessed 7 June 2018

ASEAN Secretariat (2017) Global Megatrends Implications for the ASEAN Economic Community. Available: https://asean.org/ global-megatrends/. Accessed 7 May 2018

Balding C (2011) A re-examination of the relation between democracy and international trade. J Int Trade Econ Dev 20:585-603

Banomyong R, Cook P, Kent P (2008) Formulating regional logistics development policy: the case of ASEAN. Int J Log Res Appl 11:359-379

Bary P (2015) The time-varying impact of regional trade agreement: evidence from ASEAN. Asian Econ Fin Rev 5:1061-1075

Bottasso A, Conti M, De Sa Porto P, Ferrari C, Tei A (2018) Port infrastructures and trade: empirical evidence from Brazil. Transp Res A Policy Pract 107:126-139

Bottasso A, Conti M, Ferrari C, Tei A (2014) Ports and regional development: a spatial analysis on a panel of European regions. Transp Res A Policy Pract 65:44-55

Brooks DH (2010) Trade Facilitation and Regional Cooperation in Asia. In: Brooks DH, Stone SF (eds) Regional cooperation infrastructure, and traded costs in Asia. MA: Edward Elgar. 
Carruthers R, Bajpai JN, Hummels D (2004) Trade and logistics: an east Asian perspective. In: Krumm K, Kharas H (eds) East Asia integrates: a trade policy agenda for shared growth. The World Bank and Oxford University Press, Washington DC Christopher M (2016) Logistics \& supply chain management. Pearson Higher Ed, UK

Clark X, Dollar D, Micco A (2004) Port efficiency, maritime transport costs, and bilateral trade. J Dev Econ 75:417-450

Corbett JJ, Winebrake JJ (2009) International trade and global shipping. In: Gallagher K (ed) Handbook on trade and the environment. Edward Elgar, Cheltenham

Dee P, Findlay C, Pomfret R (2008) Trade facilitation: what, why, how, where and when? In: Brooks D, Menon J (eds) Infrastructure and trade in Asia. Edward Elgar, Northampton

Devlin J, Lee P (2005) Trade logistics in developing countries: the case of the middle east and North Africa. World Economy 28:417-450

Djankov S, Freund C, Pham CS (2010) Trading on time. Rev Econ Stat 92:166-173

Dollar D, Kraay A (2003) Institutions, trade, and growth. J Monet Econ 50:133-162

Eaton J, Kortum S (2003) Technology, geography, and trade. Econometrica 70:1741-1779

Evans C, Harrigan J (2005) Distance, time, and specialization. Am Econ Rev 95:292-313

Ferrari C, Percoco M, Tedeschi A (2010) Ports and local development: evidence from Italy. Int J Trans Econ 37:9-30

Findlay C (2007) Transport Services. In: A Handbook of International Trade in Services. Oxford University Press; 2007. http:// www.oxfordscholarship.com/view/10.1093/acprof:oso/9780199235216.001.0001/acprof-9780199235216-chapter-9. Accessed 20 July 2018

Freund CL, Mclaren JE (1999) On the dynamics of trade diversion: evidence from four trade blocs (international finance discussion papers 637). Board of Governors of the Federal Reserve System, Washington, DC

Gupta S, Goh M, Desouza R, Garg M (2011) Assessing trade friendliness of logistics services in ASEAN. Asia Pac J Mark Logist 23:773-793

Hapsari, I. M. \& Mangunsong, C (2006) Determinants of AFTA Members' Trade Flows and Potential for Trade Diversion. AsiaPacific Research and Training Network on Trade Working Paper Series No. 21

Hausman WH (2004) Supply chain performance measures. In: Harrison TP, Lee HL, Neale JJ (eds) The practice of supply chain management: where theory and application converge. Springer Science \& Media Inc, New York

Hausman WH, Lee HL, Subramanian U (2013) The impact of logistics performance on trade. Prod Oper Manag 22:236-252

Hew D (2008) Towards an ASEAN economic community by 2015. In: Asean Studies C (ed) The ASEAN community: unblocking the roadblocks. Institute of Southeast Asian Studies, Singapore

Hoffmann J, Wilmsmeier G, Lun VYH (2017) Connecting the world through global shipping networks. J Shipping and Trade 2:1-4

Hummels D (2007) Transportation costs and international trade in the second era of globalization. J Econ Perspect 21:131-154

Hummels D, Schaur G (2013) Time as a trade barrier. Am Econ Rev 103:2935-2959

Hwang DW, Hong PC, Lee DY (2017) Critical factors that affect logistics performance: a comparison of China, Japan and Korea. Int J Shipping Transp Logist 9:107-129

Korinek J, Sourdin P (2011) To what extent are high-quality logistics services trade facilitating? OECD Trade Policy Papers. OECD Publishing, Paris

Kose MA, Meredith GM, Towe CM (2004) How has NAFTA affected the Mexican economy? Review and evidence IMF Working Paper. International Monetary Fund, Washington, DC

Krugman PR (2015) International economics: theory and policy. Pearson, Boston

La Londe BJ, Powers RF (1993) Disintegration and re-integration: logistics of the twenty-first century. Int J Logist Manag 4:1-12

Lai KH (2004) Service capability and performance of logistics service providers. Transport Res Part E: Log and Transport Rev 40:385-399

Lai KH, Cheng TCE (2009) Just-in-time logistics. England, Gower Publishing, Surrey

Lai KH, Pang Y, Wong CWY, Lun WY (2015) The role of logistics in trade facilitation: Lessons from ASEAN. Global Port Research Alliance Conference Paper.

Lai KH, Wong CWY, Cheng TCE, Yeung ACL (2006) Antecedents and consequences of electronic product code adoption and its implications for supply chain management: a framework and propositions for future research. Maritime Econ Logist 8:311-330

Laird JJ, Venables AJ (2017) Transport investment and economic performance: a framework for project appraisal. Transp Policy 56:1-11

Lee PT-W, Lee T-C, Yang T-H (2013) Korea-ASEAN free trade agreement: the implications on seaborne trade volume and maritime logistics policy development in Korea. J Int Logist Trade 11:3-6, 9, $19-26$

Lee TC, Lee PT (2012) South-south trade liberalisation and shipping geography: a case study on India, Brazil, and South Africa. Int J Shipping Transport Logist 4:323-338

Lee T-C, Wu C-H, Lee PT-W (2011) Impacts of the ECFA on seaborne trade volume and policy development for shipping and port industry in Taiwan. Marit Policy Manag 38:169-189

Li MZF (1998) Air transport in ASEAN: recent developments and implications. J Air Transp Manag 4:135-144

Lim CY (2009) Southeast Asia, the long road ahead. World Scientific Publishing, Singapore

Limao N, Venables AJ (2001) Infrastructure, geographical disadvantage, transport, costs and trade. World Bank Econ Rev 15:451-479

Liu C, Wang J, Zhang H, Yin M (2018) Mapping the hierarchical structure of the global shipping network by weighted ego network analysis. Int J Shipping Transport Logist 10:63-86

Lun YHV, Cariou P (2009) An analytical framework for managing container terminals. Int J Shipping Transport Logist 1:419-436

Lun YHV, Hoffmann J (2016) Connectivity and trade relativity: the case of ASEAN. J Shipping Trade 1:11

Lun YHV, Lai KH, Wong CWY, Ng CT, Cheng TCE (2011) Research in shipping and transport logistics. Int J Shipping Transport Logist 3:1-5

Magee CS (2008) New measures of trade creation and trade diversion. J Int Econ 75:349-362

Mann CL (2012) Supply chain logistics, trade facilitation and international trade: a macroeconomic policy view. J Supply Chain Manag 48:7-14

Matsumoto H (2007) International air network structures and air traffic density of world cities. TransporRes Part E: Logist Transport Rev 43:269-282

Mcquaid R, Smyth A, Cooper J (2004) The Importance of Transport in Business' Location Decisions. Napier University Press, Edinburgh 
Memedovic O, Ojala L, Rodrigue JP, Naula T (2008) Fuelling the global value chains: what role for logistics capabilities? Int J Technol Learn, Innov Dev 1:353-374

Munim ZH, Schramm H-J (2018) The impacts of port infrastructure and logistics performance on economic growth: the mediating role of seaborne trade. J Shipping and Trade 3:1

Nesadurai HS, Djiwandono JS (2009) Southeast Asia in the global economy. ISEAS Publishing, Singapore

Nordas HK, Pinali E, Grosso MG (2006) Logistics and time as a trade barrier. OECD Trade Policy Working Papers. OECD Publishing, Paris

Okabe M, Urata S (2014) The impact of AFTA on intra-AFTA trade. J Asian Econ 35:12-31

Portugal-Perez A, Wilson J (2012) Export performance and trade facilitation reform: hard and soft infrastructure. World Dev 40:1295-1307

Ramasamy B (1994) The ASEAN free trade area: implications for Indonesia's imports. Bull Indones Econ Stud 30:149-157

Ricardo D (1817) On the principles of political economy and taxation (John Murray, London). In: P.SRAFFA (ed) The Works and Correspondence of David Ricardo, Vol. 1. Cambridge University Press, Cambridge

Schiff M, Winters LA (2003) Regional Integration and Development. World Bank, Washington D.C

Shaun N (2003) Explaining ASEAN: regionalism in Southeast Asia. Lynne Rienner Publishers, Boulder

Sida K (2009) In: ADMINISTRATION, N. B. O. T. A. S. M (ed) Trade Facilitation and Maritime Transport: The Development Agenda

Smith A (1776) An inquiry into the nature and causes of the wealth of nations. W. Stahan \& T. Cadell, London

Smyth A, Christodoulou G, Dennis N, Marwan A, Campbell J (2013) Is air transport a necessity for social inclusion and economic development? J Air Transp Manag 22:53-59

Song NH (2015) ASEAN-Japan strategic Partnership in Southeast Asia: maritime security and cooperation, Japan Center for International Exchange

Tongzon J (2011) Liberalisation of logistics services: the case of ASEAN. Int J Log Res Appl 14:11-34

Tongzon J, Cheong I (2014) The challenges of developing a competitive logistics industry in ASEAN countries. Int J Log Res Appl 17:4

Ustundag A, Tanyas M (2009) The impacts of radio frequency identification (RFID) technology on supply chain costs. Transport Res Part E: Logist Transport Rev 45:29-38

Viner J (1950) The customs union issue. Carnegie Endowment for International Peace, New York

Wignaraja G (2015) Regional trade agreement in Southeast Asia. Rougledge Handbook of Southeast Asian Economies. Routledge, New York

Wilson JS, Mann CL, Otsuki T (2004) Assessing the potential benefit of trade facilitation: a global perspective. Working Paper No. 3224. World Bank, Washington, D.C

Wong CWY, Sancha C, Gimenez C (2017) A national culture perspective in the efficacy of supply chain integration practices. Int J Prod Econ 193:554-565

Wong CWY, Lai KH, Lun VYH, Cheng TCE (2012b) A study on the antecedents of supplier commitment in support logistics operations. Int J Shipping and Transport Logist 40:5-16

Wong CWY, Lai K-H, Lun VYH, Cheng TCE (2012a) A study on the antecedents of supplier commitment in support of logistics operations. Int J Shipping and Transport Logist 4:5-16

Wong CWY, Wong CY, Boon-itt S (2013) The combined effects of internal and external supply chain integration on product innovation. Int J Prod Econ 146:566-574

Wood DF, Barone AP, Murphy PR, Daniel LW (2003) International logistics. American Management Association, New York

World Bank (2018) World development indicators GDP (current US\$). The World Bank. https://data.worldbank.org/indicator/ NY.GDP.MKTP.CD?name_desc=false. Accessed 7 May 2018

Yap WY (2019) Container trade and shipping connectivity of Vietnam: implications of comprehensive and progressive agreement for trans-Pacific partnership and 21st century maritime silk road. Int J Shipping and Transport Logist 11:94-116

\section{Submit your manuscript to a SpringerOpen ${ }^{\circ}$ journal and benefit from:}

- Convenient online submission

Rigorous peer review

- Open access: articles freely available online

- High visibility within the field

- Retaining the copyright to your article

Submit your next manuscript at $\boldsymbol{\nabla}$ springeropen.com 